Article

\title{
Advancing Respect for Labour Rights Globally through Public Procurement
}

\author{
Olga Martin-Ortega ${ }^{1, *}$ and Claire Methven O'Brien $^{2}$ \\ ${ }^{1}$ School of Law, University of Greenwich, SE10 9LS, London, UK; E-Mail: o.martin-ortega@greenwich.ac.uk \\ 2 Human Rights and Development Department, Danish Institute for Human Rights, 1403 Copenhagen, Denmark; E-Mail: \\ cob@humanrights.dk
}

* Corresponding author

Submitted: 22 June 2017 | Accepted: 2 October 2017 | Published: 14 December 2017

\begin{abstract}
Governments are mega-consumers of many manufactured products and services. As such they should in principle be able to influence workers' rights abroad via the terms of purchase contracts. Yet to date little attention has been paid to the potential of public procurement to promote respect for labour rights globally besides the international trade law framework. Building on a limited emerging scholarship and policy developments, this article addresses this gap. Section 2 considers legal definitions of public procurement and distinguishes primary and secondary aims of procurement under key international and regional procurement regimes. This highlights that, although historically used to advance labour rights domestically, these regimes have restricted public buyers' scope to advance labour rights beyond national borders. Section 3 explores new international policy frameworks on responsible global value chains and supply chains which by contrast appear to augur the greater use of public procurement to promote labour rights globally in future. Section 4 argues, supported by analysis of the limited examples available, that public buying has the potential to positively influence enjoyment of labour rights in practice. Concluding, Section 5 reflects on what the more specific impacts of public procurement in this context may be, and how public buying should complement other mechanisms for improving labour conditions across supply chains, such as social clauses in trade agreements. Finally, we outline issues for further research and the future policy agenda.
\end{abstract}

\section{Keywords}

European Union; labour rights; public procurement; social clauses; sustainable development goals; UNCITRAL; United Nations; United Nations Guiding Principles on Business and Human Rights; WTO

\section{Issue}

This article is part of the issue "Labour Standards in a Global Environment", edited by Gerda Van Roozendaal (University of Groningen, The Netherlands) and Jan Orbie (Ghent University, Belgium).

(C) 2017 by the authors; licensee Cogitatio (Lisbon, Portugal). This article is licensed under a Creative Commons Attribution 4.0 International License (CC BY).

\section{Introduction}

Over recent years a range of different tools and mechanisms to improve respect for labour rights in global supply chains have been considered. Much attention has been paid, for instance, to measures to encourage corporate social responsibility, especially by transnational corporations. Likewise social clauses in trade agreements have attracted increasing interest (International Labour Organization [ILO], 2015; Orbie, Gistelinck, \& Kerremans, 2009).

Public purchasing worldwide has a value of approximately $€ 1,000$ billion per year and accounts for $12 \%$ of
GDP, on average across OECD countries (OECD, 2017a). Governments are mega-consumers of many manufactured products and certain types of services. In principle, therefore, they should be able to influence working conditions by exercising leverage over their immediate suppliers and, through supply chain requirements, in turn over other companies involved in the production process. Yet to date little scholarly attention has been paid to the potential of public procurement to promote respect for labour rights globally.

In this article we continue to address this gap (MartinOrtega, Outhwaite, \& Rook, 2015; Methven O'Brien \& 
Martin-Ortega, 2017; Methven O'Brien, Mehra, \& Vander Meulen, 2016; Outhwaite \& Martin-Ortega, 2016; see also Barnard, 2013; De Schutter, 2014; Northern Ireland Human Rights Commission, 2013; Stumberg et al., 2014) with a focus on public procurement's place in the international trade regime and its potential role as a complement to social clauses in trade agreements. Section 2 considers legal definitions of public procurement and distinguishes primary and secondary aims of procurement under key international and regional procurement regimes, namely the WTO Plurilateral Agreement on Government Procurement (GPA), the Model Law on Public Procurement of the United Nations Commission on International Trade Law (UNCITRAL) and the European Union's procurement Directives. In doing so, it highlights that, whereas public procurement has often been used historically to advance labour rights domestically, these frameworks currently restrict public buyers' scope to advance labour rights within and beyond national borders.

Section 3 explores recent international policy developments relating to responsible supply chains. These, by contrast, appear to augur the greater use of public procurement to promote respect for labour rights, globally. Section 4 provides examples of cases that suggest that harnessing public buying towards this goal can be effective in practice. Based on this discussion, Section 5 reflects on what the various impacts of using public procurement as a mechanism for promoting labour rights globally may be, and how it may serve as a complement to other efforts to improve labour conditions across supply chains, such as labour clauses in trade agreements. Finally, we outline issues for further research and the future policy agenda.

Throughout this article we differentiate labour rights, being workers' rights as established in national and international law; labour or/working conditions, as the factual conditions under which goods are produced; and human rights, as defined by international human rights instruments and which include the rights recognised by the ILO's Declaration on Fundamental Principles and Rights at Work ("Core Labour Standards") but not all labour rights as just defined. Similarly, we refer to procurement and labour rights, rather than social clauses in procurement contracts, or the language of labour clauses used by ILO Convention No. 94 in order to distinguish between the use of procurement to advance domestic social policies and the use of public procurement to promote respect for labour rights beyond national borders.

\section{Linking Public Procurement and Labour Rights: Opportunities and Limitations}

\subsection{Defining Procurement}

Public procurement refers to the purchase by the public sector of the goods and services it needs to carry out its functions (Arrowsmith \& Kunzlik, 2009, p. 9). Such goods and services range widely, from infrastructure projects and the acquisition of complex weapon systems, to the commissioning of essential public services in the health and social care sector and the purchase of common manufactured or processed goods such as stationery, furniture, uniforms, personal electronic items and foodstuffs.

In legal terms, procurement comprises three main phases: procurement planning; the procurement process; and contract administration or management. During procurement planning, the specific requirements of the public body in question are established and publicised, including via: technical specifications for the product or service; the award criteria which will be used to select the winning bid; and contract performance clauses which will be included in the future contract. In the second phase, the public buyer undertakes a tender procedure to solicit bids from potential suppliers to fulfil the given contract. One supplier is then selected following a comparative evaluation of bids received in line with the pre-established award criteria. After this, contractual terms and conditions are drafted, including specific performance conditions. The third step aims to secure effective contractual performance (Trepte, 2006).

Government purchases falling within the scope of domestic public procurement regimes may be subject, in addition, to relevant areas of general law (for example, administrative, contract, environmental and anticorruption laws). Depending on their monetary value, subject matter and obligations entered into by the state, they may also be subject to international rules (for instance, under the WTO GPA), regional regimes (such as the European Union's procurement Directives) and international finance instruments (Trepte, 2006, p. 42).

\subsection{Primary and Secondary Aims of Public Buying}

Whether national, supranational or international, procurement rules generally define the principal policy objectives or "primary" aims of public buying as including: a) the achievement of value for money ("efficiency"); b) non-discrimination between tenderers; and c) open competition. However, governments have sometimes sought to use public purchasing to promote "secondary" policy aims, that is, social, environmental or other societal objectives that are not necessarily connected with the procurement's functional objective (Arrowsmith \& Kunzlik, 2009, p. 9).

As early as 1936 the ILO considered establishing minimum standards for those directly employed in public works and producing goods and services for the public sector (ILO, 2008, p. 2). In 1949 it adopted the Labour Clauses (Public Contracts) Convention (No. 94), followed and supplemented by Recommendation No. 84. The stated rationale for these instruments has been that public buyers should seek to ensure the observance of socially acceptable labour conditions in relation to work performed on the public's account (ILO, 2008, p. 5). The temptation to economise on the cost of public works by reducing labour protections should be resisted and gov- 
ernments "should not be seen as entering into contracts involving the employment of workers under conditions below a certain level of social protection, but on the contrary, as setting an example by acting as model employers" (ILO, 2008, p. 1). Under these ILO instruments the required level of labour protection is set by reference to pre-existing national standards, while the scope of government obligations under them is domestic. Their main goal is therefore to ensure consistent conditions for workers in a given country, whether labouring in the service of the public or private sector, albeit they may indirectly tend to promote labour rights elsewhere by discouraging "race to the bottom" dynamics.

Likewise, initiatives by individual governments linking public procurement and labour protections have traditionally focused on national constituencies, in particular marginalised or disadvantaged groups, aiming to secure their integration into the domestic labour market (McCrudden, 2007), typically through so-called social clauses. Such linkages have hence generally been referred to as social procurement. "Green" procurement, focused on reducing the environmental impacts of public buying, rose in prominence during the 1990s. The Agenda 21 plan resulting from the 1992 Rio Earth Summit, for example, called for governments to exercise environmental leadership through public purchasing (para. 4.23), giving rise to further green procurement initiatives by international organisations such as the OECD and United Nations (McCrudden, 2007, p. 390; Perera, Chowdhury, \& Goswami, 2007).

In this context, the terminology of "social" and "green" procurement is gradually giving way to that of "sustainable procurement", encompassing both these dimensions (Steurer, Berger, Konrad, \& Martinuzzi, 2007). D'Hollander and Marx (2014, p. 5) thus refer to sustainable public procurement "as a broad concept covering a variety of practices that aim to integrate social and environmental criteria in purchasing decisions of government actors". Such a notion is reflected, for instance, in the International Standards Organisation's [ISO] new Sustainable Procurement Guidance (ISO, 2017). This defines sustainable procurement as purchasing decisions that meet an organisation's needs in a way that benefits them, society and the environment and ensures that an organisation's suppliers behave ethically, that the products and services purchased are sustainable and that purchasing decisions help to address social, economic and environmental issues as well as any risks to human rights (ISO, 2017).

Yet while the beneficiaries of environmental measures integrated into public buying may be globally dispersed, "social" procurement as historically practiced has as noted focused on participants in local labour markets, marking a clear distinction from the scope and intention of social clauses in trade agreements. This indeed explains the more recent emergence of "socially responsible", "ethical" or "fair" public procurement initiatives seeking to address labour conditions beyond the borders of the purchasing country by integrating requirements addressing respect for the rights of workers in countries of production (European Fair Trade Association, 2010; Swedwatch, 2016, p. 9).

\subsection{Procurement Law Regimes: Limitations and Opportunities}

Given their market weight, public buyers should in principle be able to advance respect for labour rights globally through such initiatives. However, procurement law has often operated to curtail this influence in practice. In mediating between procurement law's primary aimsefficiency, non-discrimination and open competition, as earlier noted-and "secondary" policy objectives such as respect for labour rights, procurement law regimes traditionally have favoured the former. This is evident, for example, in the lack of interest states, have shown in applying the 1949 ILO Convention. "Modern" public procurement has rather prioritised competition even if "promoting competition at all costs among potential contractors, go[es] against the Convention's aim of requiring the application by all bidders of the best locally established working conditions" (ILO, 2008, p. xiii). Hence attempts to advance labour rights via public procurement beyond state borders have encountered challenges somewhat similar to those faced by social clauses in trade agreements, that is, legal resistance on grounds of market distortion and protectionism (Hanley, 2002; McCrudden, 2007, Chapters 4, 11; McCrudden \& Gross, 2006). In one salient example, the European Union challenged 1996 State of Massachusetts (United States) legislation (Act Regulating State Contracts with Companies Doing Business with or in Burma [Myanmar]) which restricted the ability of public bodies to contract with companies doing business in Myanmar under the WTO GPA as discriminatory against non-United States companies (Fitzgerald, 2001; Martin-Ortega \& Eroglu, 2008).

Over recent years, a trend towards greater accommodation of secondary objectives across procurement law regimes can be seen as emerging. As indicated by the following analysis, on the other hand, relevant legal developments have remained focused on social considerations within rather than beyond national borders.

The WTO GPA is a pluri-lateral agreement applying only to WTO members who have chosen to accede to it. At the time of writing this group comprised 19 parties covering 47 WTO members (the European Union and its member states constitute one party). Another 29 WTO members and four international organisations participate in the GPA Committee as observers, of which ten members are in the process of GPA accession (WTO, 2017). The GPA's stated objectives are greater liberalisation and expansion of international trade; non-discrimination (that is, measures prepared, adopted or applied to public procurement must not afford greater protection to domestic suppliers, goods or services, or discriminate against foreign suppliers, goods, or services); integrity and pre- 
dictability, to ensure efficient and effective management of public resources; and transparency, impartiality, avoidance of conflicts of interest and corruption.

Because of these principles the original GPA was restrictive of states' ability to advance secondary objectives via public procurement (Arrowsmith \& Anderson, 2011). A Revised GPA text adopted in 2012 exhibits greater tolerance of environmental and social policy linkages. First, it permits derogations from its general regime where "necessary to protect human, animal or plant life or health" (Art. III.2.b). Second, it allows measures intended to advance environmental protection (Art. X.6 authorises technical specifications which "promote the conservation of natural resources or protect the environment," while the indicative list of evaluation criteria in Art. X.9 includes environmental characteristics). Third, the scope of the revised Agreement excludes "procurement conducted for the specific purpose of providing international assistance, including development aid" (Art. II.3). While measures to advance respect for labour rights are not explicitly mentioned, it has been suggested that they may permitted so long as they accord with other provisions of the Agreement (Thrasher, 2014). This regime applies only to signatories of the GPA which are, for the most part, OECD countries. Accordingly, other countries would be free to put in place procurement regimes which are more flexible regarding the achievement of social goals (see De Schutter's argument regarding procurement schemes to further food security and the right to food in De Schutter, 2014, pp. 17, 19).

UNCITRAL is an organ of the United Nations General Assembly established to promote the harmonisation and unification of international trade. The UNCITRAL Model Law on Public Procurement aims to encourage the uniform development of national procurement laws globally in line with the principles of competition guiding the WTO (Arrowsmith \& Nicholas, 2009; Nicholas, 2009,2011 ) while also helping states to achieve "value for money" and avoid abuses in the procurement process (for instance, corruption). It informs the public procurement regimes of 23 states, the Organisation of Security and Cooperation in Europe, the World Bank, the African, Asian and Inter-American Development Banks and the European Bank for Reconstruction and Development.

In its Preamble, the Model Law sets out six main objectives: economy and efficiency; international trade; competition; fair and equitable treatment; integrity, fairness, and public confidence in the procurement process; and transparency. At the same time the Model Law allows for the integration of social and economic criteria, such as promoting accessibility of procurement to small and medium sized enterprises (SMEs) or disadvantaged groups, environmental criteria and ethical qualification requirements, into procurement processes (Art. 9.2.b). A recently issued Guide to Enactment accompanying the 2011 version of the Model Law, which superseded UNICTRAL's 1994 Model Law, notes that human rights can feature as social aspects of sustainable procurement, and can be addressed through socio-economic evaluation criteria (Art. 11 and United Nations Commission for International Trade, 2014, pp. 78-82, 85-89). It also provides that a Public Procurement Agency or similar body can be tasked to review procurement proceedings to ensure that procuring entities have respected applicable laws (United Nations Commission for International Trade, 2014, pp. 21-22). Though this provision was drafted with the intention of referring to procurement law, it might be given broader application so as to extend to human rights laws, especially where they are incorporated into domestic law or where human rights receive constitutional protection.

In the European Union, the award of public contracts above a certain monetary value by Member State authorities is required to comply with the principles of the Treaty on the Functioning of the European Union (TFEU) and the "four freedoms" guaranteed by the European Union's legal regime, namely, free movement of goods, services, capital, and people within European Union boundaries as well as principles deriving therefrom, such as equal treatment, non-discrimination, mutual recognition, proportionality and transparency. Hence, public procurement may limit cross-border flows in these four areas only if restrictions are imposed in pursuit of the public interest while also meeting certain other conditions (Court of Justice of the European Union [CJEU], Reyners v. Belgium, 1974).

Relevant government purchases must also comply with the European Union's specialised procurement regime. Currently this includes Directive 2014/24 [the Public Sector Directive] and Directive 2014/25 which regulates procurement by entities operating in the water, energy, transport and postal services sector [the Utilities Directive]. The European Union's previous procurement Directives (Directives 2004/18 and 2004/17) were particularly restrictive of public buyers' freedom to refer to secondary considerations. Still, over the ten years leading up to adoption of the 2014 Directives, public buyers sought increased flexibility, while European Commission policy also evolved in this direction, as reflected in several rounds of interpretative guidance (European Commission, 2004, 2010). As regards the CJEU, though it had addressed secondary considerations already prior to the 2004 Directives (Commission of the European Communities v. French Republic [Nord-Pas de Calais], 2000; Concordia Bus Finland v. Helsingin kaupunki \& HKL-Bussiliikenne, 2002; Gebroeders Beentjes BV v. The Netherlands, 1988), subsequent decisions reflect persisting tensions between primary and secondary (mainly environmental) criteria under the 2004 regime. In Wienstrom (EVN AG and Wienstrom GmbH v. Republic of Austria, 2003), for example, it was held lawful to use an ecological award criterion and to establish an award criterion that is related to the production method of the purchased product, as long as such a criterion is relevant for the contract and is expressly linked to its subject matter. Evropaïki Dynamiki v. European Environment Agency 
(2010) considered whether a public purchaser could, under the 2004 Directive, refer to whether bidders had a general environmental policy as part of award criteria. While the court held that they could, it noted that a buying authority's discretion in assessing bids was restricted. Though a purchaser could refer to third party certifications as evidence of a supplier's environmental standards, it could not require certifications as such. In the Max Havelaar case (European Commission v. The Netherlands, 2012) it was held that award criteria may concern aspects of the production process that do not materially alter the final product, so that fair trade label requirements can constitute elements of contract performance under public contracts.

The 2014 Directives were intended to modernise public procurement in the European Union by increasing the efficiency of public spending, facilitating the participation of SMEs and enabling public bodies to use procurement to further common societal goals, including sustainability. Thus the 2014 Public Sector Directive draws links directly to sustainable development both in its recitals and provisions (Recitals 2, 41, 47, 91, 93, 95, 96, 123 and Arts. 2(22), 18(2), 42(3)(a), 43, 62, 68, 70). While public authorities must still ensure that they are linked to the subject matter of the procurement, there is now greater flexibility to integrate environmental and social criteria, for instance, with reference to fair trade labels (Outhwaite \& Martin-Ortega, 2016). In addition, the Directive requires member states to take appropriate steps to ensure that in the performance of public contracts, economic operators comply with applicable social, environmental and labour law obligations (art. 18.2), the latter being defined with reference to the ILO's Core Labour Standards (Annex 10). It also provides for exclusion of economic operators from relevant tenders following convictions for offences including child labour or human trafficking (Art. 57(1)(f)). On the other hand, states are still forbidden from requiring economic operators to commit to corporate social responsibility or other sustainability measures that cannot be "linked" to the specific goods or services purchased (Outhwaite \& Martin-Ortega, 2016). This would seem to exclude, for instance, the use of public buying to promote corporate non-financial reporting or companies' uptake of human rights due diligence as called for by the 2011 UN Guiding Principles on Business and Human Rights and OECD Guidelines for Multinational Enterprises (Methven O'Brien et al., 2016). As this analysis shows, even if the present European Union regime is becoming more enabling of social procurement, the scope it permits to use public tenders to advance respect for labour rights globally remains limited, as it does under the WTO GPA. Whilst tensions within the European Union procurement law regime, in particular between their primary and secondary aims, and between procurement laws and labour protections remain (Bundesdruckerei GmbH v. Stadt Dortmund, 2014; Dirk Rüffert v. Land Niedersachsen, 2008; RegioPost GmbH \& Co. KG v. Stadt
Landau in der Pfalz, 2015), recent developments appear to suggest a policy shift is underway that may alter this position, as discussed in the following section.

\section{Linking Public Procurement and Labour Rights Globally: New Policy Frameworks}

A wave of initiatives by global actors have identified a transition to "responsible" or "sustainable" global value chains as critical to the achievement of sustainable development, inclusive global growth and decent work. Such initiatives strongly emphasise the need for "responsible business conduct" in achieving these goals, that is, business conduct "contributing positively to economic, environmental and social progress with a view to achieving sustainable development" and avoiding and addressing adverse impacts in value chains, be these produced by their own activities or through their business relationships (OECD, 2017b). In 2015, addressing "Responsible Supply Chains", the G7 Leaders' Declaration committed to strive "for better application of internationally recognized labour, social and environmental standards, principles and commitments (in particular UN, OECD, ILO and applicable environmental agreements) in global supply chains". It further recognised that governments and business have a joint responsibility "to foster sustainable supply chains and encourage best practices", calling for tools to support public procurers in meeting social and environmental commitments (White House, 2015). Referring to "Sustainable Global Supply Chains", the 2017 G20 Leaders' Declaration undertook to "work towards establishing adequate policy frameworks in our countries" to "foster...the implementation of labour, social and environmental standards and human rights in line with internationally recognised frameworks" (G20, 2017). The ILO recently approved its Revised Programme of Action 2017-21 regarding Decent Work in Global Supply Chains with the aim of assisting ILO member States to make "significant strides in reducing the governance gaps and decent work deficits in global supply chains, thereby strengthening the role of supply chains as engines of inclusive and sustainable growth" (ILO, 2017, para. 6). In the European context, the "responsible management of global supply chains" has been identified as essential "to align trade policy with European values" (European Union Trade for All (2015) strategy, 4.2.3.) There is a thus an increased focus on integrating respect for human rights, including ILO Core Labour Standards, into supply chain standards and management. For the OECD, "responsible business conduct" implies in particular that companies undertake human rights due diligence as defined by the UN Guiding Principles on Business and Human Rights (UNGPs). In turn, the UNGPs indicate that companies' responsibility to respect human rights extends beyond their own operations to the activities of business partners, including suppliers and subcontractors, wherever they are located (Martin-Ortega, 2014; Methven O’Brien \& Dhanarajan, 2016). 
Even if aimed primarily at business, at the same time new supply chain standards inevitably turn the spotlight on government consumption. Besides the corporate "responsibility to respect" human rights, the UNGPS affirm a "State duty to protect" that extends to interactions between states and businesses of a commercial nature. UNGP 1 provides that "States shall take appropriate steps to prevent, investigate, punish and redress [business-related human rights abuses] through effective policies, legislation, regulation and adjudication". As UNGP 6 notes, this entails that states should promote awareness and respect for human rights by businesses in the context of public procurement, while UNGP 5 recalls that, where states privatise or "contract out" public services, they retain their human rights obligations and must "exercise adequate oversight" to ensure these are met, including by ensuring that contracts or enabling legislation communicate the state's expectation that service providers will respect the human rights of service users. UNGP 4 meanwhile provides that states should, where appropriate, require state-owned or controlled enterprises to exercise human rights due diligence, implicitly encompassing their purchasing function, and UNGP 8 calls for "policy coherence" to be achieved by alignment of goals and practice across governmental departments, agencies and institutions.

Adopted by UN Member States in 2015, the 2030 Agenda for Sustainable Development also sets new objectives on public procurement as part of the drive towards sustainable production and consumption and more inclusive economies. Sustainable Development Goal 12.7 calls on all countries to promote sustainable public procurement practices and to implement sustainable public procurement policies and action plans. Most recently, following in the wake of analysis and advocacy by scholars and civil society practitioners (International Learning Lab on Public Procurement and Human Rights, n.d.; Martin-Ortega \& Davies, 2017; Methven O'Brien et al., 2016), the OECD has also acknowledged links between public procurement, its responsible business agenda and sustainable development (OECD, 2017), while the ISO's Sustainable Procurement Guidance (ISO, 2017) as mentioned above urges the integration of human rights as well as green and other considerations across public and private supply chain management.

\section{Linking Public Procurement and Labour Rights Globally: Emerging Practices}

Beyond recognition of connections between public purchasing and labour rights globally at the level of high policy, examples are also emerging of links made by specific national regulatory initiatives as well as successes by individual public bodies in using procurement to advance respect for workers' rights in practice. This section analyses some of these examples. Full analysis of the extent of relevant practice and its impacts, on the other hand, is not yet possible given the shortage of accessible data relating to most public contracts (Open Contracting Partnership, 2017) and while survey data still scarcely touch on social, labour or human rights issues (United Nations Environment Programme, 2017).

In the United States, some measures intended to combat labour abuses abroad have been in place for some time. The 1936 Walsh-Healey Act for instance prohibits federal agencies from purchasing sweatshop goods for contracts of a value greater than $\$ 10,000$. Sweatshop labour is defined with respect to compliance in the country of production with applicable rules regarding minimum wages, maximum working hours, child and convict labour, and health and safety. Yet, ironically, imported goods were exempt, so that the Act applied only to goods produced in the United States, Puerto Rico, and the Virgin Islands (Stumberg et al., 2014).

As a more contemporary initiative, provisions were introduced into the Federal Acquisitions Act (Prohibition of Acquisition of Products Produced by Forced or Indentured Child Labor) in 1999 to prohibit forced child labour in contracts sourced abroad beyond a "micro" purchase threshold. In support of this measure the U.S. Department of Labor is required to prepare a "List of Products Requiring Contractor Certification as to Forced or Indentured Child Labor". In their turn contractors must certify that they either a) will not sell a product on the list or b) they have made a good-faith effort to determine whether forced child labour was used (Stumberg et al., 2014).

In 2015, in addition, by inserting the Combating Trafficking in Persons Section into the Federal Acquisition Regulation, a series of provisions were introduced to prohibit federal government contractors and subcontractors from supporting or engaging in human trafficking, which is defined to include, amongst other things, forced labour and fraudulent or coercive recruitment or employment practices. Contractors are required to report any credible allegations of trafficking to the contracting agency's Inspector General and must cooperate with government investigations. For contracts for goods (excluding commercially available off-the-shelf items) or services sourced outside of the United States that exceed $\$ 500,000$, the Government also requires that contracting businesses prepare compliance plans detailing due diligence procedures to assess, prevent, mitigate, and remediate any suspected involvement (Methven O'Brien et al., 2016).

Several other initiatives pursue similar goals at state and local level in the United States by leveraging the collective purchasing power of government buyers (see Methven O'Brien et al., 2016). The Sweatfree Purchasing Consortium (SPC) comprises 14 U.S. cities and 3 U.S. states that seek to ensure that the apparel products they buy are made without sweatshop labour (Sweatfree Purchasing Consortium, 2017). The municipal government of San Francisco, for example, requires its apparel suppliers to comply with laws in the country of production as well as ILO Core Labour Standards (Sweatfree Purchasing Consortium, 2014a). San Francisco has, in the past, retained 
the Worker Rights Consortium (an independent labour rights monitoring organisation) to survey its apparel supply chains and report on contractors' compliance with its code (Sweatfree Purchasing Consortium, 2014a). Another example is the City of Madison, Wisconsin, which released a request for proposals for uniforms for its police, fire, and metro workers in 2014 (Sweatfree Purchasing Consortium, 2014b). Madison required all bidders to disclose information on factory location, wages, and hours, for a minimum of $60 \%$ of factories to be used in production of goods for the contract. The awarded contractor was required to increase this disclosure by $10 \%$ each year and provide compliance action plans from all manufacturers producing goods for the contract above a certain value threshold. Finally, the SPC has created an online database (Sweatfree LinkUp!) where information about apparel vendors, manufacturers, and factories in government supply chains is publically available. The information is sourced from apparel vendors and manufacturers themselves, and in some cases government entities that require supply chain disclosures as part of the procurement process. A similar initiative in Europe addresses public purchasing of electronics hardware. Electronics Watch supports public bodies seeking to address human rights abuses in their ICT supply chains and provides model contract conditions for inclusion in procurement agreements. The Electronics Watch Contract conditions are designed to meet primary requirements under procurement laws while also including a Code of Labour Practices for suppliers containing human rights and labour safeguards, and encouraging suppliers to disclose factory locations to purchasers so that labour conditions can be monitored (Electronics Watch, n.d.).

Although it is not generally applicable to public authorities, the UK's Modern Slavery Act (2015) has nonetheless provided a strong impulse for public buyers to review forced labour and human trafficking risks in their supply chains. In particular, Higher Education Institutions are subject to the reporting obligation established by the Act in its Transparency in Supply Chains section. Hence UK universities have had to produce statements for the financial year 2015-2016 addressing their efforts to identify, prevent and mitigate modern slavery and human trafficking in their supply chains (MartinOrtega, 2016; Martin-Ortega \& Islam, 2017).

Also in the UK, individual contracting authorities, directly or through collaboration, are inserting contract clauses in their contracts to demand due diligence in supply chains from suppliers. For example, since 2016 all UK universities can also rely on a new agreement for the purchase of Apple devices using the iOS operating system. This agreement includes a contract clause allowing public buyers to demand respect for labour rights by suppliers (as defined in an attached Code of Labour Practices) and requiring suppliers to adopt transparent supply chain management practices and respond to reports of labour rights abuses. The agreement and clauses are devised with reference to templates provided by Elec- tronics Watch. In 2016, too, the London Universities Purchasing Consortium included a similar set of contract clauses in its framework agreement on cleaning and security services. Transport for London (TfL) is another example of an individual public purchaser pursuing measures to extend respect for labour rights. It has adopted an Ethical Sourcing Policy, linked to the Ethical Trading Initiative's Base Code, according to which it aims to improve labour conditions in the supply chain of relevant product categories or specific products. Suppliers under contracts that include TfL's ethical sourcing provisions are also required to monitor conditions via third party audits and provide TfL with results, while TfL undertakes to collaborate with suppliers to remedy breaches (TfL, 2017).

According to the Netherlands' National Action Plan (NAP) to implement the UNGPs, its national sustainable procurement policy requires companies supplying goods and services to public bodies to respect human rights as part of the "social conditions" applicable to all central government European Union contract award procedures since 1 January 2013 (Dutch Ministry of Foreign Affairs, 2014). Suppliers may meet the social conditions by a variety of means, such as participating in a multistakeholder supply chain initiative or undertaking risk analysis. PIANOo, the government's tendering expertise centre, has published a step-by-step guide addressing how to meet the social conditions at each phase of the tender-procedure (PIANOo, 2017). In this context, the Dutch NAP commits to evaluate the social conditions for consistency with the OECD Guidelines for Multinational Enterprises and UNGPs, and their potential extension to municipal, provincial, and water authorities.

Sweden's County Councils are responsible for healthcare, public transportation and regional planning, together accounting for about $€ 13$ billion per year through procurement (Hemstrom, 2016). Since 2010, the County Councils have collaborated in efforts to promote respect for labour rights, including using a common code of conduct for suppliers, follow-up questions to review suppliers' compliance with the code, and targeted factory audits conducted either by the County Councils themselves or by an independent party. In 2012 the Councils established a formalised structure with a National Coordinator for social responsibility, Steering Committee, National Coordinator, Expert Group, and point of contact at each county council. The Councils have prioritised seven categories of goods for social criteria in public procurement, including surgical instruments worth approximately $€ 267,000$ annually.

As a final example, in Norway public authorities are obliged to advance contract clauses on wages and decent working conditions when purchasing services such as construction, facility management, and cleaning services. Public authorities are also required to follow up with suppliers on performance of such clauses, for instance, by requiring the supplier to make a self-declaration (Methven O'Brien et al., 2016, p. 25). 
As regards the impacts of such measures, published evidence is limited. A 2015 report published by the NGO Swedwatch described an investigation into the effects on working conditions in factories producing surgical instruments in Pakistan of the above-mentioned measures introduced by Sweden's County Councils. This study found a substantial reduction in serious labour rights abuses, including child labour, in workshops producing for the County Councils while labour conditions in neighbouring workshops showed no such improvement over the same period (Swedwatch \& British Medical Association, 2015). In 2016 Electronics Watch reported that conditions in factories producing for Dell had improved as a result of an intervention by the Swedish County Councils demanding action to eliminate labour abuses including forced student labour, earlier revealed to be taking place there (Electronics Watch, 2016). Similarly, the British Medical Association found in 2016 that its "naming and shaming" efforts had triggered changes in the procurement of surgical gloves and other items whose production had been documented as violating workers' basic labour rights in the British health sector (British Medical Association, 2016 , 2017). On the other hand, two recent studies reviewing the impact of the policy requiring the application "social conditions" to public tenders in the Netherlands, mentioned above, reached less optimistic assessments. One found the conditions were, in practice, rarely applied to relevant tenders (SOMO, 2014) while the other found that, even if applied during this phase of the procurement, whether suppliers fulfilled the required terms during the performance of the contract was not monitored or verified (PIANOo, 2014).

These examples show how certain public buyers are developing practices which aim to improve respect for labour rights in the lower tiers of the supply chain and are driving suppliers to improve their practices. By passing labour clauses down the value chain, suppliers to governments have at least in some cases had a proven impact in improving "ultimate" conditions (Van den Putte, 2017).

\section{Conclusion}

The cases explored in the previous section offer some encouraging signs. They suggest that procurement regimes may be starting to exhibit a greater responsiveness to concerns to facilitate the use of public buying to advance labour rights protections globally. They demonstrate an appetite on the part of at least some governments and buyers at subsidiary levels of the state to drive respect for labour rights worldwide. If appropriately formulated and communicated, suppliers can respond positively to demands from public buyers for products and services whose supply chains respect Core Labour Standards, with positive impact on ultimate working conditions of those working in its lower tiers. In combination, these results suggest that public procurement should be viewed as a potentially important instrument to increase respect for labour standards worldwide. A small set of examples nonetheless remains an incomplete basis for firm conclusions about the scope for public procurement's systematic use to drive respect for labour rights globally. Indeed, a number of obstacles stand in the way of such an assessment. As discussed, accessible data is generally lacking as regards the content of public contracts in most countries and comprehensive public procurement surveys still generate scant information on social, labour or human rights issues. Almost no studies to date have attempted to document or measure the effects of socially responsible procurement practices, whether intermediate or ultimate, across jurisdictions. Many sustainable procurement practices have in any case been too recently adopted to permit full evaluation of their influence on labour conditions throughout global production processes. In addition, as analysed in Section 2, tensions within procurement law regimes remain, specifically regarding their primary and secondary aims, and between procurement laws and labour protections.

As this article has demonstrated there is also a significant gap in the literature regarding the scope of public buyers' human rights obligations in relation to domestic and foreign workers. How procurement laws should interact specifically with human rights norms under other specialised international and supranational legal regimes is just beginning to be explored (Methven O'Brien \& Martin-Ortega, 2017; Outhwaite \& Martin-Ortega, 2016, p. 61). Another gap we have identified relates to how the international human rights and international trade law regimes should interface in this context. Whilst the link between labour rights and trade has been on research and policy agendas for two decades, it is only recently that studies documenting and classifying the effectiveness of labour clauses in trade agreements are emerging (ILO, 2015; Van den Putte, 2017). We suggest that the use of public procurement to advance labour rights globally should now be integrated into this scheme, with public buying considered as a complementary tool to social clauses in trade agreements, and the development of theoretical and methodological instruments to analyse and measure its impact and effectiveness a priority.

At least rhetorically, supply chain sustainability has recently risen to the top of the international policy agenda. Given this, and the opportunities presented, for instance, by the Sustainable Development Goals, as well as increasing political pressures on higher income countries' development assistance budgets, this focus, we suggest, is an urgent one. If appropriately devised public procurement can be demonstrated to deliver progress towards decent work transnationally, a much greater share of government, scientific and social resources should be diverted towards supporting it.

\section{Acknowledgments}

We would like to acknowledge Dr. Jan Orbie and Dr. Gerda Van Roozendaal for their thorough editorial work, 
whose comments and suggestions have assisted us greatly. We are also indebted to the anonymous reviewers. Finally, we would like to acknowledge the work of Ozge Okay and Marisol Bernal Corredor in the final editorial process. All errors remain our own.

\section{Conflict of Interests}

The authors declare no conflict of interests.

\section{References}

Arrowsmith S., \& Anderson, R. (Eds.). (2011). The World Trade Organisation regime on government procurement: Challenge and reform. Cambridge: Cambridge University Press.

Arrowsmith, S., \& Kunzlik, P. (2009). Social and environmental policies in EU procurement law: New directives and new directions. Cambridge: Cambridge University Press.

Arrowsmith, S., \& Nicholas, C. (2009). The UNCITRAL model law on procurement of goods, construction and services: Past, present and future. In S Arrowsmith (Ed.), Reform of the UNCITRAL model law on procurement: Procurement regulation in the 21st century (pp. 4-5). Eagan, MN: West.

Barnard, C. (2013). Using procurement law to enforce labour standards, In G. Davidov \& B. Langille (Eds.), The idea of labour law (pp. 256-272). Oxford: Oxford University Press.

British Medical Association. (2016). Ethical procurement guidance for general practitioners and clinical commissioning groups. British Medical Association. Retrieved from file://C:/Users/om3025c/ Downloads/Ethical-Procurement-for-GPs\%20(2).pdf

British Medical Association (2017). In good hands: Tackling labour rights concerns in the manufacture of surgical gloves. British Medical Association. Retrieved from https://www.bma.org.uk/collective-voice/influ ence/international/global-justice/fair-medical-trade /medical-gloves-report

Bundesdruckerei GmbH v. Stadt Dortmund, C-549/13, EU:C:2014:2235 (2014).

Commission of the European Communities v. French Republic, C-225/98 E.C.R. I-7445 (2000).

Concordia Bus Finland v. Helsingin kaupunki \& HKLBussiliikenne, Case C-513/99, E.C.R. I-7213 (2002).

D'Hollander, D., \& Marx, A. (2014). Strengthening private certification systems through public regulation. The case of sustainable public procurement. Sustainability Accounting, Management and Policy Journal, 5(1), 2-21.

De Schutter, O. (2014). The power of procurement. Public purchasing in the service of realizing the right to food (United Nations Special Rapporteur on the Right to Food Briefing Note 08). New York, NY: United Nations. Dirk Rüffert v. Land Niedersachsen, C-346/06, ECR I-1989 (2008).
Dutch Ministry of Foreign Affairs. (2014, April). National action plan on business and human rights. Retrieved from https://business-humanrights.org/ sites/default/files/documents/netherlands-nationalaction-plan.pdf

Electronics Watch. (2006, February). Public procurement and human rights due diligence to achieve respect for labour rights standards in electronics factories: A case study of the Swedish county councils and the Dell computer corporation. Electronics Watch. Retrieved from http://electronicswatch.org/ en/publications_1633

European Commission v. The Netherlands, C-368/10, EU:C:2012:284 (2012).

European Commission. (2004). Buying green! A handbook on green public procurement. Luxembourg: Publications Office of the European Union.

European Commission. (2010). Buying social: A guide to taking account of social considerations in public procurement. Luxembourg: Publications Office of the European Union.

European Fair Trade Association. (2010). State of play of fair trade public procurement in Europe. Brussels: European Fair Trade Association.

European Commission. (2017). G20 leaders' declaration: Shaping an interconnected world (Press Release). European Commission. Retrieved from http://europa. eu/rapid/press-release_STATEMENT-17-1960_en.htm

EVN AG and Wienstrom GmbH v. Republic of Austria, C448/01, E.C.R. I-14527 (2003).

Evropaïki Dynamiki v. European Environment Agency, C331/06, E.C.R. II-136 (2010).

Fitzgerald, P. L. (2001). Massachusetts, Burma, and the World Trade Organization: A commentary on blacklisting, federalism, and internet advocacy in the global trading era. Cornell International Law Journal, 34(1), 13-19.

Gebroeders Beentjes BV v. The Netherlands, C-31/87, E.C.R. 4635, (1988).

Hanley, C. (2002). Avoiding the issue: The Commission and human rights conditionality in public procurement. European Law Review, 6, 714-735.

Hemstrom, K. (2016). Sustainable IT webinar series, best practice sustainable it procurement. TCO Certified. Retrieved from http://tcodevelopment.com/ news/watch-webinar-on-demand-best-practice-sus tainable-it-procurement

International Labour Organisation. (2008). Report III (Part 1B). General Survey concerning the labour clauses (public contracts) convention, 1949 (No. 94) and recommendation (No. 84) (Report of the Committee of Experts on the Application of conventions and Recommendations). Geneva: International Labour Office.

International Labour Organisation. (2015). Social dimensions of free trade agreements. Geneva: International Institute for Labour Studies.

International Labour Organisation (2017). Revised ILO 
programme of action 2017-21. Geneva: International Labour Office. Retrieved from http://www.ilo. org/wcmsp5/groups/public/---ed_norm/---relconf/ documents/meetingdocument/wcms_545657.pdf

International Organization for Standardization. (2017). Sustainable procurement guidance (ISO Standard No. 20400:2017). Retrieved from https://www. iso.org/standard/63026.html

Martin-Ortega, O. (2014). Human rights due diligence for corporations: From voluntary standards to hard law at last? Netherlands Quarterly of Human Rights, 32(1), 44-74.

Martin-Ortega, O. (2016). Modern slavery and human rights in global supply chains: Roles and responsibilities of public buyers. Policy and practice insights for Higher Education Institutions in the framework of their obligations under the UK Modern Slavery Act (BHRE Research Series. Policy Paper n. 2). Retrieved from http://www.bhre.org/policy-papers

Martin-Ortega, O., \& Davies, A. (2017). Protecting human rights in the supply chain. A guide for public procurement practitioners (Version 1.0). London: Chartered Institute of Procurement and Supply.

Martin-Ortega, O., \& Eroglu, M. (2008). The European Unions' corporate social responsibility strategy: A pole of excellence? In J. Orbie \& L. Torrell (Eds.), The European Union and the social dimension of globalisation (pp. 166-185). Oxon: Routledge.

Martin-Ortega, O., \& Islam, R. (2017). UK Modern Slavery Act 2015 transparency in supply chains: The first year of reporting by universities (BHRE Research Series, Report 1). London: BHRE Research Series.

Martin-Ortega, O., Outhwaite, O., \& Rook, W. (2015). Buying power and working conditions in the electronics supply chain: Legal options for socially responsible public procurement. International Journal of Human Rights, 19(3), 341-368.

McCrudden, C. (2007). Buying social justice. Equality, government procurement and legal change. Oxford: Oxford University Press.

McCrudden, C., \& Gross, S. G. (2006). WTO government procurement rules and the local dynamics of procurement policies: A Malaysian case study. European Journal of International Law, 17(1), 151-185.

Methven O'Brien, C., \& Dhanarhajan, S. (2016). The corporate responsibility to respect human rights. A status review. Accounting, Auditing and Accountability Journal, 29(4), 542-567.

Methven O'Brien, C., \& Martin-Ortega, O. (2017). Human rights and public procurement: Towards a holistic International law analysis (Unpublished Working Paper prepared for the International Law Association Study Group on Business and Human Rights).

Methven O'Brien, C., Mehra, A., \& Vander Meulen, N. (2016). Public procurement and human rights: A survey of 20 jurisdictions. International Learning Lab on Public Procurement and Human Rights. Retrieved from http://www.hrprocurementlab.org/ blog/reports/public-procurement-and-human-rights -a-survey-of-twenty-jurisdictions

Nicholas, C. (2009). The UNCITRAL model law: An example for the global community. In H. García (Ed.), International public procurement: A guide to best practice (pp. 19-34). London: Globe Law and Business.

Nicholas, C. (2011). Work of UNCITRAL on government procurement: Purpose, objectives, and complementarity with the work of the WTO. In S. Arrowsmith \& R. Anderson (Eds.), The WTO regime on government procurement: Challenge and reform (pp. 746-772). Cambridge: Cambridge University Press.

Northern Ireland Human Rights Commission. (2013). Public procurement and human rights in Northern Ireland. Retrieved from http://www.nicshuman rightsguide.com/uploads/files/NIHRC_Public_Procur ement_and_Human_Rights.pdf

OECD. (2017a). Public procurement. OECD. Retrieved from http://www.oecd.org/gov/ethics/public-procu rement.htm

OECD. (2017b). Responsible business conduct in government procurement practices. Retrieved from http:// mneguidelines.oecd.org/Responsible-business-con duct-in-government-procurement-practices.pdf

Open Contracting Partnership. (2017). Website. Open Contracting Partnership. Retrieved from https:// www.open-contracting.org

Outhwaite, O., \& Martin-Ortega, O. (2016). Human rights in global supply chains: Corporate social responsibility and public procurement in the European Union. Human Rights and Legal Discourse, 10(1), 54-73.

Orbie, J., Gistelinck, M., \& Kerremans, B. (2009). The social dimension of EU trade policies. In J. Orbie \& L. Tortell (Eds.), The European Union and the social dimension of globalisation (pp. 148-165). Oxon: Routledge.

Perera, O., Chowdhury, N., \& Goswami, A. (2007). State of play in sustainable public procurement, International institute for sustainable development. Manitoba: International Institute for Sustainable Development.

PIANOo. (2014). Social conditions in global supply chains. PIANOo. Retrieved from https://www.pianoo.nl/ about-pianoo/sustainable-public-procurement-spp/ spp-themes/social-conditions-in-global-supply-chains

PIANOo. (2017). Getting started with social conditions in global supply chains. PIANOo. Retrieved from https://www.pianoo.nl/about-pianoo/sustainablepublic-procurement-spp/spp-themes/social-condi tions-in-global-supply-chains/getting-started-withsocial

RegioPost GmbH \& Co. KG v. Stadt Landau in der Pfalz, C-115/14, EU:C:2015:760 (2015)

Reyners v. Belgium, C-2/74, E.C.R. 631 (1974).

Steurer, R., Berger, G., Konrad, A., \& Martinuzzi, A. (2007). Sustainable public procurement in EU member states: Overview of government initiatives and selected cases. Vienna: Research Institute for Managing Sustainability. 
SOMO. (2014). A review of Dutch policy for socially responsible public procurement. Amsterdam: SOMO. Retrieved from https://www.somo.nl/wp-content/ uploads/2014/03/A-review-of-Dutch-policy-for-social ly-responsible-public-procurement.pdf

Stumberg, R., Ramasastry, A., \& Roggensack, M. (2014). Turning a blind eye? Respecting human rights in government purchasing. Washington, DC: ICAR. Retrieved from http://icar.ngo/initiatives/procurement

Sweatfree Purchasing Consortium. (2014a). City of San Francisco, California (Sweatfree Purchasing Advisory Group, Annual Report 4). Retrieved from http:// sfgov.org/olse/sweatfree-contracting-ordinance

Sweatfree Purchasing Consortium. (2014b). City of Madison, Wisconsin, uniform management program request for proposals. Sweatfree Purchasing Consortium. Retrieved from http://buysweatfree.org/ uniform_management_program

Sweatfree Purchasing Consortium. (2017). Website. Sweatfree Purchasing Consortium. Retrieved from http://buysweatfree.org

Swedwatch. (2016). Agents for change. How public procurers can influence labour conditions in global supply chains. Case studies from Brazil, Pakistan and Thailand (Report no. 86). Retrieved from http:// www.swedwatch.org/wp-content/uploads/2016/11/ 82_Agents-for-Change-enkelsidor.pdf

Swedwatch and British Medical Association. (2015). Healthier procurement: Improvements for working conditions for surgical instrument manufacture in Pakistan (Report no. 73). Retrieved from file:/// C:/Users/om3025c/Downloads/PO-HealthierProcur ement_BMA-10-04-2015.pdf
The White House. (2015). G-7 leaders' declaration (Press Release). Retrieved from https://www.g7germany. de/Content/EN/_Anlagen/G7/2015-06-08-g7-absch luss-eng_en.pdf;jsessionid=1B9B0A7130CEB8CC4F9 E9834CE0870C2.s2t2? blob=publicationFile\& $v=3$

Thrasher, R. (2014). On fairness and freedom: The WTO and ethical sourcing initiatives. Boston University. Retrieved from http://www.bu.edu/pardee/research/ global-economic-governance-2/wtoethicalsourcing

Transport for London. (2017). Ethical sourcing policy. Retrieved from http://content.tfl.gov.uk/tfl-ethicalsourcing-policy.pdf

Trepte, P. (2006). Regulating procurement: Understanding the ends and means of public procurement regulation. Oxford: Oxford University Press.

United Nations Commission for International Trade. (2014). Guide to enactment of the UNCITRAL model law on public procurement. Retrieved from http:// www.uncitral.org/pdf/english/texts/procurem/mlprocurement-2011/Guide-Enactment-Model-Law-Pu blic-Procurement-e.pdf

United Nations Environment Programme. (2017). Global review of sustainable public procurement. United Nations Environment Programme. Retrieved from http://www.scpclearinghouse.org/resource/2017-glo bal-review-sustainable-public-procurement

Van den Putte, L. (2017). The EU's trade-labour linkage: Beyond the 'soft' approach? (Unpublished doctoral thesis). Ghent University, Ghent, Belgium.

World Trade Organization. (2017). Agreement on government procurement: What is the GPA? World Trade Organization. Retrieved from https://www.wto.org/ english/tratop_e/gproc_e/gp_gpa_e.htm

\section{About the Authors}

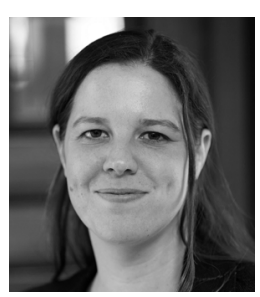

Olga Martin-Ortega is Reader in Public International Law at the School of Law, University of Greenwich, where she leads the Business, Human Rights and the Environment Research Group (BHRE). Her research focuses on business and human rights, transitional justice and post-conflict reconstruction. She is co-editor (with Claire Methven O'Brien) of Public procurement and Human Rights: Opportunities, Risks and Dilemmas for the State as Buyer (Edward Elgar, forthcoming [2018]).

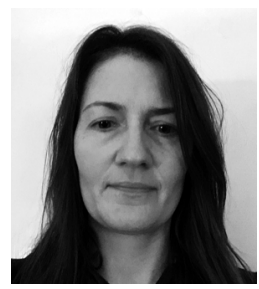

Claire Methven O'Brien is Strategic Adviser on Human Rights and Business at the Danish Institute for Human Rights. She is a Visiting Fellow at the International Law Department of the University of Groningen and was previously Research Fellow at LSE's Centre for the Study of Human Rights. Claire is co-editor (with Olga Martin Ortega) of Public procurement and Human Rights: Opportunities, Risks and Dilemmas for the State as Buyer (Edward Elgar, forthcoming [2018]). 